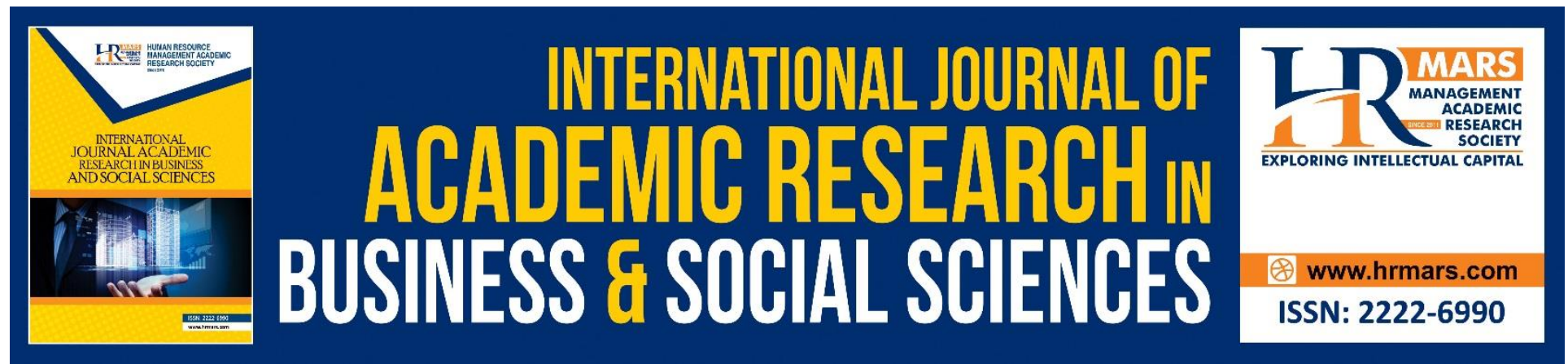

\title{
Development of HRM Training Practice under Saudi Arabia's Vision 2030
}

Nader Saeed Alkhater, Layla Alhalwachi

To Link this Article: http://dx.doi.org/10.6007/IJARBSS/v8-i9/4705

DOI: $10.6007 /$ IJARBSS/v8-i9/4705

Received: 06 August 2018, Revised: 27 August 2018, Accepted: 29 Sept 2018

Published Online: 15 October 2018

In-Text Citation: (Alkhater \& Alhalwachi, 2018)

To Cite this Article: Alkhater, N. S., \& Alhalwachi, L. (2018). Development of HRM Training Practice under Saudi Arabia's Vision 2030. International Journal of Academic Research in Business and Social Sciences, 8(9), 14051419.

Copyright: (C) 2018 The Author(s)

Published by Human Resource Management Academic Research Society (www.hrmars.com)

This article is published under the Creative Commons Attribution (CC BY 4.0) license. Anyone may reproduce, distribute, translate and create derivative works of this article (for both commercial and non-commercial purposes), subject to full attribution to the original publication and authors. The full terms of this license may be seen

at: http://creativecommons.org/licences/by/4.0/legalcode

Vol. 8, No. 9, September 2018, Pg. 1405 - 1419

http://hrmars.com/index.php/pages/detail/IJARBSS

JOURNAL HOMEPAGE

Full Terms \& Conditions of access and use can be found at http://hrmars.com/index.php/pages/detail/publication-ethics 


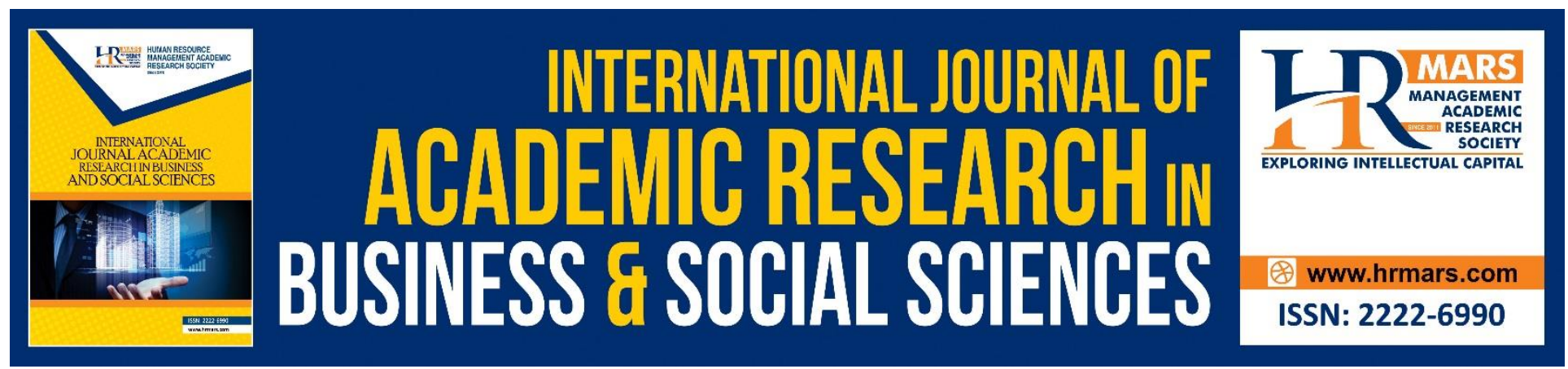

\title{
Development of HRM Training Practice under Saudi Arabia's Vision 2030
}

\author{
Dr. Nader Saeed Alkhater a, Dr. Layla Alhalwachi ${ }^{b}$ \\ ${ }^{a}$ Ericsson Telcom , Saudi Arabia , ${ }^{b}$ Business School, Bahrain Polytechic, Kingdon of Bahrain
}

\begin{abstract}
This paper studies the development in the human resources management training of domestic enterprises (DEs) Vs. multinational subsidiaries (MNSs) under Saudi Vision 2030 was formed in 25 April 2016 by Crown Prince Mohammad bin Salman. Based on the literature MNSs are more rigorous in their training practices. So, the hypotheses were predicted from literature as MNSS are more interested in their training. Findings were confirmed that predicted hypotheses were statistically significant. MNSs utilized more sophisticated training practice. Also, this paper considered the comparative in terms of local Saudi workforce. When MNSs have more local force were found to place more significance on training development . The literature was explored in order to confirm this study is only one in the context of Saudi Arabia. This study was added to understand of HRM practices between two different types of organizations. Furthermore, this study had suggestion for future research.
\end{abstract}

Keywords: Multinational Subsidiaries, Domestic Enterprises, Training; Appraisal, Mann-Whitney

\section{Introduction}

As business activities are becoming more worldwide, international management in general, and international human resource management (IHRM) in particular, have become significant research areas. Barney and Wright (1998) commented that HRM has played an important rule to enhance organizational performance. The main critical problem for both multinational and domestic organizations is to find the balance between global and local in designing and implementing HRM practices (Aycan ,2005). In addition, a key factor in the success of any organization is the way in which employees are trained within the organization (Mohamed et al., 2012 and Singh et al., 2013).

The term HRM can define of strategic rather than reactive, prescriptive and administrative. It is defined as the extent to the formulation and implementation of HRM strategies. In addition, the pattern of planned human resource deployments and activities projected to enable an organization to achieve its aims could be the definition of HRM (Andrews and Chompusri 2005). 
According to Akhtar et al., (2008) and Ahmad and Schroeder (2003) there are seven human resources that enhance organizational performance: internal career opportunities, formal training systems, results-oriented appraisals, employment security, participation, job descriptions, and profit sharing. The strategic HRM manages employees and improves organizational performance (Farnham , 2010).

Aycan (2005) posit DEs try to create culturally appropriate HRM systems that enable them to compete globally. The firms need to jump from local market to international market to improve efficiency, for instance, Unilever and Procter\& Gamble required for greater scale efficiency and more globally development by providing better coordination (Bartlett and Ghoshal 1987).

Batt (2002) confirmed that the employees must have a high performance and behavior to attract customer to buy product from firm. To attract customer to buy the product of firm and service, employee need to be smart and aware about product (i.e, service agreements, pricing, packaging, promotions for particular customer segments, and legal regulations).

\section{Literature Review}

The HR practices highlighted in this paper were training and appraisal. One of the most important key to successes any organization is human resources management (HRM). HRM was considered more important than other asset in any organization (Barney and Wright 1998). Also, enhancement the organizational performance is depended on HRM practices. According to Akhtar et al., (2008) the training and appraisal are important factors that keeps organization live in the market. In addition, sophisticated technologies and innovative manufacturing practices are not sufficient to enhance organization performance without HRM practices (Ahmad \& Schroeder, 2003).

On the other hand, Barney and Wright (1998) show some organizations decide the man power is the low priority in the firms. For instance, when the firm needs to reduce the cost, it looks to cut the benefits of employee (i.e training, wage and headcounts). Comparative research has long been important in the field of industrial relations (Boxall, and Purcell, 2003).

The HRM must have the ability to manage a multinational workforce by selecting employee, training, appraisal and reward system (Adler and Jelinek 1986). Furthermore, Ahmad \& Schroeder (2003) have proposed seven HRM exercises to enhance organizational performance. The exercises proposed by them are: Employment security, Selective hiring of new personnel, Self-managed teams and decentralization of decision, making as the basic principles of organizational design, comparatively high compensation contingent on organizational performance, extensive training, and wage differences across level and extensive sharing of financial and performance information throughout the organization. The employer secures a good work place and motivate to employee will be resulted high output from worker (Baron, 1988).

In contrast, HRM was criticized by adding value or not be contributed to improve organization performance (Andrews and Chompusri 2005). HRM has authority to control man power by reducing labor cost. Also, the HRM is considered to understand the relationship between turnover and organizational performance. However, the turnover will be going high if the 
INTERNATIONAL JOURNAL OF ACADEMIC RESEARCH IN BUSINESS AND SOCIAL SCIENCES Vol. 8, No. 9, Sept. 2018, E-ISSN: 2222-6990 ㄷ 2018 HRMARS

benefits and compensations will be given to senior employee rather than new employee (Arthur, 1994).

Some international market has jumped to high level of performance by running HRM practice in the organization. For instance, Chinese economy had developed with high organizational performance, as it moves into HRM configuration in enterprises. This high performance is recognized where knowledge workers become more predominant.

Some of HR practices are demonstrated in this research that are training and development. Aycan (2005) showed HRM practices in six key areas: human resource planning and career management; job analysis and design; recruitment and selection; performance appraisal; compensation and reward management and training and development. The HRM practices toward of improving organizational effectiveness and hence better performance outcomes.

\section{Training and Development}

Training and development are formed in one part called formal training system. There is quite different between the training and the development that tanning is more specific when compared to development. Winterton (2007) defined training as the process of which employee is provided with the important components to perform his role and motivate employee to use these skills in the organization. In addition, other researchers defined training as the process by that human being changes his skills, knowledge, attitudes and behavior (Robbins and Cenzo, 1998). However, the processes that focus on growth employee and career movement employee are called development.

Training targets at improving current work skills and behavior while increasing abilities in relation to future position and enhance employability can be defined as development (Waterman, 1994). Some programs of formal training systems are extended by adding job rotation, monitoring, lectures and simulation exercise (DeCenzp and Robbins, 2005).

Training and development has been generally reported as they have a positive impact on employee motivation and performance (Singh, Mohamed and Darwish, 2013). Aycan (2005) posits training topics are usually based on supervisors' recommendations. The training and development of employee is varying between organizations. For example, the universal culture is selected trainees on their evaluation performance. In contrast, selection for training is not based primarily on performance, but on group membership on other organizations. The training is more required in countries with workforces with limited skill and organizations place greater value on training and development to stay competitive and to attract the best people in the labor market (Aycan, 2005). The employee who has experience will earn more knowledge in training than fresh employee. Also, providing training in earlier jobs will increase earnings growth to employee (Booth, 1993). Training is expanded into designing and supporting learning activities. The main factor of achieving objective of the organization by contributing to the satisfaction and productivity of employee is training system (Dearden, Reed and Reenen, 2006). The training and 
INTERNATIONAL JOURNAL OF ACADEMIC RESEARCH IN BUSINESS AND SOCIAL SCIENCES Vol. 8, No. 9, Sept. 2018, E-ISSN: 2222-6990 @ 2018 HRMARS

development to employee will be generated high earn profits to an organization (Kalleberg and Moody, 1994 and Harel and Tzafrir, 1999).

Table 2.1 shows, training and development have been argued by many scholars such as (Singh et al., 2013; Booth, 1993; Kalleberg and Moody, 1994; Harel and Tzafir, 1999; Way, 2002; Dearden, Reed and Reenen, 2006, Brewster and Bournois, 1991; Wilson and Madsen, 2008; Snape et al., 1998) that training, and development have impacted on employee motivation and organization performance has been observed. The formal training system could be differed in MNSs and could be in the same when they operate in host countries. For example, macro level variables such as functional and technological structure have been converged. However, micro level variables such as behavior of people have been diverging. In addition, the formal training system is important in MNSs to expatriate and also important to host country nationals. The training will provide development and will enhance the quality in MNSs operate in the host country. One more study conducted in Germany, local firms were found to use more on the job training systems than their UK and USA counterparts (Muller, 1998).

Based on the confirmations formed above, the hypothesis number one is stated as follows:

H1: Important differences of formal training system will be noted in between DEs and MNSs

H2: In term to, the MNSs and DEs with high size of Saudi manpower would be more likely interesting in training than firms with small size of Saudi manpower.

\section{Problem on the Literature}

One of the most important factor that impact on organizational performance is HRM practices. Most of the previous researches focused on developing HRM practices to employees (Dyer and Batt, 1992 and Lawler et al., 1995). Bartlett and Ghoshal (1998) commented that majority of the firms concerned in global level rather than regional market. There are many challenges to firms when converging on global scales due to different culture and different values of countries (Locke and Kochan 1995). Therefore, we need to understand the methods of how human resources practices adapt in different culture. The majority researches of HRM practices focused in western cultures and not apparent in other part of Asian countries (Singh et al., 2013). Until now, there is shortages to of HRM in the Kingdom of Saudi Arabia due to limited study in this area (Anderson, Ahmed \& Costa, 2012; Fadhel, 2007; Al-Dosary \& Rahman, 2009). This research focused in training and development practices to see values differences between two groups in the Kingdom of Saudi Arabia.

\section{Data Collection and Sample}

Data of this study are formed from human rescores directors of MNSs and DEs working in the kingdom of Saudi Arabia. The roots of Saudi Arabia are traced to the earliest civilizations that occurred in the Arabian Peninsula. Through the years, the role of the peninsula in history has been evidenced. It has served as an ancient centre of trade (Royal Embassy of Saudi Arabia, 2015). In addition, it has served as the birthplace or foundation of Islam considered one of the main religions in the world. Since the establishment of the modern Saudi Arabian Kingdom by King Abdulaziz Al Saud in the year 1932, the transformations have been remarkable. In a few decades, Saudi Arabia has transformed from a largely desert country to a modern complex state besides being a key player on the global arena. The state of Saudi Arabia was established in the year 1932 
following a three decade-long campaign to have the Arabian Peninsula unified. After the invasion of Kuwait by Iraq in 1990, the kingdom accepted the royal family from Kuwait and four hundred thousand refugees while permitting Arab and Western forces on its soil to free Kuwait. The presence of foreign troops after Kuwait's liberation triggered tension between the people and the royal family till 2003 when all troops left the kingdom. There were major campaigns against terrorism following the terrorist attacks in 2003. Between 2005 and 2015, King Abdullah worked to modernize the nation using socio-economic programs. Saudi Ministry of commerce and Industry of KSA exposed a total of 1,544 joint stocks firms working in KSA. This research was selected joint stock company to participate on the data collection as population.

The sample size is selected in random sample technique according the below Slovin's formula:

$$
\begin{aligned}
n=N /\left(1+N e^{2}\right) & =1,544 /\left(1+1,544 * 0.05^{2}\right)= \\
& =1544 / 4.86=317.7 \approx 318 \mathrm{firms}
\end{aligned}
$$

Where,

$\mathrm{n}=$ Number of samples,

$\mathrm{N}=$ Total population and

$E=$ Error tolerance equal to 0.05 due to this value suitable to management study.

A sample size of $\mathbf{3 1 8}$ was created from the population of MNSs and DEs.

primary data collected from 255 firms, two-thirds of which were DEs whilst the remaining onethird were MNEs. Data that were analyzed with the help of parametric and non-parametric tests revealed several interesting facts.

\section{Factor Analysis of Training}

The training had acceptable KMO ranges value $(\mathrm{KMO}=0.88)$, as shown in Table1. The factor analysis of training unitary result did not require rotation, only due to one component being extracted, as shown in Table 2. The six elements were included in the analysis with no individual element deleted.

Table 1: Exploratory Factor Analysis of Training

\begin{tabular}{|l|l|l|l|}
\hline Construct & & & Component \\
\cline { 2 - 4 } & Item & Comments & 1 \\
\hline \multirow{4}{*}{ Methods of training } & TR1 & Formal instruction within the organisation & .863 \\
\cline { 2 - 4 } & TR2 & Training provided by a third-party organisation & .850 \\
\cline { 2 - 4 } & & $\begin{array}{l}\text { Informal apprenticeship to an } \\
\text { experienced member of the organisation }\end{array}$ & .858 \\
\cline { 2 - 4 } & TR3 & $\begin{array}{l}\text { Induction into a group to learn by } \\
\text { socialisation and imitation }\end{array}$ & .823 \\
\cline { 2 - 4 } & TR4 & .789 \\
\cline { 2 - 4 } & TR5 & Learning by doing on your own & .744 \\
\cline { 2 - 4 } $\begin{array}{l}\text { Percentage of variance Unrotated Factor Solution } \\
\text { Cronbach's Alpha }\end{array}$ & TR6 & Work replacement with strategic partners & 67.6 \\
\hline
\end{tabular}


INTERNATIONAL JOURNAL OF ACADEMIC RESEARCH IN BUSINESS AND SOCIAL SCIENCES

Vol. 8, No. 9, Sept. 2018, E-ISSN: 2222-6990 @ 2018 HRMARS

Total Variance Explained: 67.6

Kaiser-Meyer-Olkin Measure of Sampling Adequacy 0.88

Bartlett's Test of Sphericity: Approx. Chi-square: 931.7

Df: 15

Sig:.000

Source: Author's analysis of data

Table 2: Extraction Method: Principal Component Analysis

\begin{tabular}{|l|l|l|l|l|l|l|}
\hline \multirow{2}{*}{ component } & \multicolumn{3}{|l|}{ Initial Eigenvalues } & \multicolumn{3}{l|}{ Extraction Sums of Squared Loadings } \\
\cline { 2 - 7 } & & $\begin{array}{l}\text { \% of } \\
\text { Variance }\end{array}$ & $\begin{array}{l}\text { Cumulative } \\
\%\end{array}$ & Total & \% of Variance & $\begin{array}{l}\text { Cumulative } \\
\%\end{array}$ \\
\hline 1 & 4.063 & 67.714 & 67.714 & 4.063 & 67.714 & 67.714 \\
2 & 0.635 & 10.584 & 78.298 & & & \\
3 & 0.499 & 8.320 & 86.619 & & & \\
4 & 0.310 & 5.174 & 91.792 & & & \\
5 & 0.269 & 4.486 & 96.279 & & & \\
6 & 0.223 & 3.721 & 100.000 & & & \\
\hline
\end{tabular}

T-test

The training system has one part that asked the question 'What are the most applicable methods of training new employees in junior management?' that divided to six methods were coded on a 5 - point Likert scale with ' 1 ' not important and ' 5 ' very important. The independent T-Test was used to toct romnaricnnc hotwosen two indenendent groups due to training variables was meet the nor Source: Author's analysis of data

Table 3 shows the significant differences between MNEs vs DEs, with MNEs subsidiaries also utilising more sophisticated training practice. The multinational subsidiaries place more emphasis on all six methods: 'Formal instruction within the organisation $(t=-13.674, M D=-1.706$, $p<0.001)$, 'Learning by doing on your own ( $t=-13.472, M D=-2.012, p<0.001)$, 'Training provided by a third party organisation TR2' $(\mathrm{t}=-12.098, \mathrm{MD}=-1.768, \mathrm{p}<0.001)$, 'Induction into a group to learn by socialisation $-T R 4$ ' $(\mathrm{t}=-10.56, \mathrm{MD}=-1.637, \mathrm{p}<0.01)$, Work replacement with strategic partners' ( $t=-15.082, M D=-2.21 ., p<0.001)$, 'Informal apprenticeship to an experienced TR3' $(t=-8.354, t=-1.647, p<0.01)$. Figure 1 shows the weight of the mean of MNEs is higher than in DEs with all six attributes. Thus, the results indicate MNEs as being good with performance in training when compared with DEs. H1 was significantly correct in that "Important differences of formal training system will be noted in between DEs and MNSs" 
INTERNATIONAL JOURNAL OF ACADEMIC RESEARCH IN BUSINESS AND SOCIAL SCIENCES Vol. 8, No. 9, Sept. 2018, E-ISSN: 2222-6990 @ 2018 HRMARS

Table 3: T-Test of training

\begin{tabular}{|c|c|c|c|c|c|}
\hline Case & $\mathrm{OL}$ & $\mathrm{N}$ & Mean & T-Test & $\begin{array}{l}\text { Mean } \\
\text { D }\end{array}$ \\
\hline \multirow{2}{*}{$\begin{array}{l}\text { Formal instruction within the } \\
\text { organisation }\end{array}$} & DEs & 175 & 2.27 & \multirow{2}{*}{$13.674 * * *$} & \multirow[b]{2}{*}{-1.706} \\
\hline & MNES & 80 & 3.98 & & \\
\hline \multirow{2}{*}{$\begin{array}{l}\text { Training provided by a third- } \\
\text { party organisation }\end{array}$} & DEs & 175 & 2.32 & \multirow{2}{*}{$12.098 * * *$} & \multirow[b]{2}{*}{-1.768} \\
\hline & MNES & 80 & 4.09 & & \\
\hline \multirow{2}{*}{$\begin{array}{l}\text { Informal apprenticeship to an } \\
\text { experienced member of the } \\
\text { organisation }\end{array}$} & DEs & 175 & 2.58 & \multirow[b]{2}{*}{$-8.354 * * *$} & \\
\hline & MNES & 80 & 3.94 & & -1.355 \\
\hline \multirow{2}{*}{$\begin{array}{l}\text { Induction into a group to learn } \\
\text { by socialisation and imitation }\end{array}$} & DEs & 175 & 2.50 & \multirow{2}{*}{$-10.56^{* * *}$} & \multirow[b]{2}{*}{-1.647} \\
\hline & MNES & 80 & 4.15 & & \\
\hline \multirow[t]{2}{*}{ Learning by doing on your own } & DEs & 175 & 2.26 & \multirow{2}{*}{$13.472 * * *$} & \multirow[b]{2}{*}{-2.012} \\
\hline & MNES & 80 & 4.28 & & \\
\hline \multirow{2}{*}{$\begin{array}{l}\text { Work replacement with } \\
\text { strategic partners }\end{array}$} & DEs & 175 & 2.18 & \multirow{2}{*}{$15.028 * * *$} & \multirow[b]{2}{*}{-2.21} \\
\hline & MNES & 80 & 4.39 & & \\
\hline
\end{tabular}

Source: Author's analysis of data

*Significant at the 0.10 level. ** Significant at the 0.05 level. *** Significant at the 0.01 level.

Figure 1: Mean compared of training between MNEs vs DEs

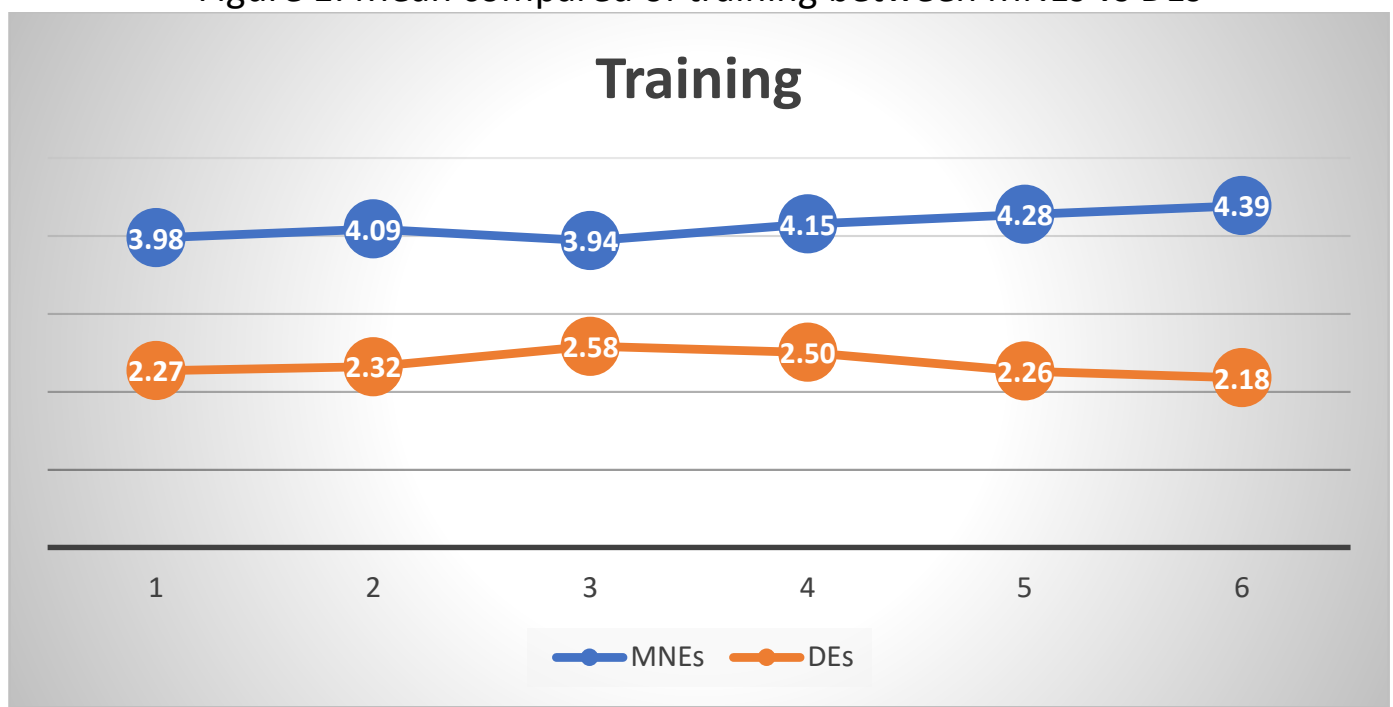

Source: Author's analysis of data

Note: 1. Formal instruction within the organisation, 2 . Training provided by a thirdparty organisation, 3. Informal apprenticeship to an experienced member of the organisation, 4. Induction into a group to learn by socialisation and imitation, 5. Learning by doing on your own, 6 . Work replacement with strategic partners. 
INTERNATIONAL JOURNAL OF ACADEMIC RESEARCH IN BUSINESS AND SOCIAL SCIENCES Vol. 8, No. 9, Sept. 2018, E-ISSN: 2222-6990 ㄷ 2018 HRMARS

*Significant at the 0.10 level. ** Significant at the 0.05 level. *** Significant at the 0.01 level.

\section{Multivariate Analysis Regression}

Training practice was defined by six elements regarding the most applicable methods of training new employees in junior management. Table 4 describes the six models: formal instructions within the company; training provided by a third-party organisation but tailored to company needs; informal apprenticeship to an experienced member of the organisation; induction into a group by socialisation and imitation; learning by doing on your own; work placement with strategic partners. Additionally, 13 control variables in the table column one of Table 4 were described in the footnotes.

In order to conduct multivariate analysis for training, we defined six individual footnotes. The six models were eligible to describe the relation between dependent variables and independent variables as Table 4 in the last row defines the F-value as being statistically significant to all six models at level 0.01 .

The first result observed from Table 4 suggested that industrial firms are working in the oil and chemical sector, and that these have not influenced the training: as shown, there is no statistical significance in row 8 . This result indicates that the oil sector may not care about training employees due to firms being likely to recruit experienced employees during recruitment and selecting method to junior management. Additionally, Table 4 in row 6 shows that formal instructions within the company $(\beta=0.309, p<0.05)$ and learning by doing on your own $(\beta=0.551$, $p<0.01$ ) and work were statistically significant. However, other schemes of training methods were not statically significant due to may be the training provided by a third-party organization was not interesting to new local employees. Furthermore, "the informal apprenticeship to an experienced member of the organization", "Induction into a group by socialisation and imitation" and "Work placement with strategic partners" were not statically Signiant due to the local new employees like to gain training within dependent on himself.

This result indicates that firms with large local employees will be linked partially positively with training system. This result indicated that $\mathrm{H} 2$ was partially correct. 
INTERNATIONAL JOURNAL OF ACADEMIC RESEARCH IN BUSINESS AND SOCIAL SCIENCES

Vol. 8, No. 9, Sept. 2018, E-ISSN: 2222-6990 @ 2018 HRMARc

Table 4: Regression Results on the Training Practice

\begin{tabular}{|l|r|r|r|r|r|r|}
\hline Predictors & \multicolumn{1}{l|}{ Model 1 } & \multicolumn{1}{l|}{ Model 2 } & \multicolumn{1}{l|}{ Model 3 } & \multicolumn{1}{l}{ Model 4 } & \multicolumn{1}{l|}{ Model 5 } & \multicolumn{1}{l}{ Model 6 } \\
\hline Employee Age & $0.365^{* * *}$ & $0.466^{* * *}$ & $0.6859^{* * *}$ & $0.576804^{* * *}$ & -0.132 & -0.158 \\
\hline Employee Experience & -0.102 & $0.25^{* *}$ & $0.373^{* *}$ & $0.305^{*}$ & 0.038 & -0.126 \\
\hline Firm Age & 0.040 & $0.251^{*}$ & 0.249 & -0.097 & 0.041 & -0.007 \\
\hline Firm Size & 0.172 & 0.100 & $0.301^{*}$ & $0.446^{* * *}$ & -0.048 & $0.26^{*}$ \\
\hline Sales Revenue & 0.063 & 0.021 & -0.271 & $0.37^{*}$ & 0.199 & -0.006 \\
\hline local labour force & $0.309^{* *}$ & -0.165 & 0.167 & -0.035 & $0.551^{* * *}$ & -0.123 \\
\hline OL & $1.58^{* * *}$ & $1.45^{* * *}$ & $1.148^{* * *}$ & $1.286^{* * *}$ & $1.710^{* * *}$ & $2.13^{* * *}$ \\
\hline Industry & 0.032 & 0.075 & 0.309 & 0.181 & -0.199 & 0.309 \\
\hline M structured & -0.083 & -0.156 & -0.055 & -0.094 & -0.021 & -0.042 \\
\hline $\begin{array}{l}\text { Organisation } \\
\text { structured }\end{array}$ & 0.157 & -0.141 & -0.127 & -0.066 & -0.164 & 0.086 \\
\hline Foreign ownership & -0.093 & -0.134 & 0.032 & 0.037 & 0.086 & -0.204 \\
\hline Location & -0.164 & -0.115 & -0.199 & -0.218 & -0.175 & 0.141 \\
\hline Turnover & -0.100 & -0.072 & $0.327^{*}$ & 0.196 & -0.080 & $0.38^{* *}$ \\
\hline F-Value & $21.133^{* * *}$ & $15.67^{* * *}$ & $11.062^{* * *}$ & $12.625^{* * *}$ & $16.195^{* * *}$ & $22.858^{* * *}$ \\
\hline
\end{tabular}

Source: Author's Analysis of Data

*** significant at 0.01 level; ${ }^{* *}$ significant at 0.05 level; * significant at 0.10 level.

Note: Models 1-6 are responses to the question: 'What are the most applicable methods of training new employees in junior management?' (variables 1-6).The 6 replies read as follows: 1. Formal instructions within the company; 2. Training provided by a third-party organisation but tailored to company needs; 3 . Informal apprenticeship to an experienced member of the organisation; 4 . Induction into a group by socialisation and imitation; 5 . Learning by doing on your own; 6 . Work placement with strategic partners.

The 13 control variables in column of predictors are as follows: 1. Age of HR Director; 2. Experience of HR Director; 3. Firm age; 4. Firm size; 5 . Sales Revenue; 6. Local labour; 7. Operation level MNE or DE; 8. Industry 9. Method Structured; 10. Organisation Structured; 11. Foreign ownership 12. Firm Location;12.Turnover. 


\section{Main Findings}

The hypotheses were devised in line with various theories, to be summarised below. First hypothesis (H1) was found to be completely true, whereas second once was only partially true.

Shiwaku (2014) compared three multinational subsidiaries MNE in Japan vs DEs in Armenia, which found Japan is higher in training than Armenia. Teachers' training programmes' in Armenia is expected to be improved through the application of the essences of teacher training. Additionally, DEs are more likely to participate in employee training than MNEs in Germany (Muller, 1998). However, the differences in training were numerous; US MNSs are more concerned with training (Wong and Brinbaum, 1994). Mohamed et al. (2012) added that MNSs are more stringent in their training and rigorous with promotion practices when compared with DEs in Brunei Darussalam. The first hypothesis ( $\mathrm{H} 1$ ) was found to be significant, with the results echoed in the literature review. The differences in training between DEs vs MNEs were found to exist.

The second hypothesis $(\mathrm{H} 2)$ concerns on firms having large size of local employees will be increased organization performance. Forstenlechner (2009) agreed that the large size of local employee demonstrates a positive link with the training systems, and therefore impacted on the high output of profit performance. Snape \& Redman (2010) confirmed no evidence to suggest a relationship between training systems and employee behaviour exists. The current research in table 4 confirms the large size of local employees as partially connected with the training system.

\section{Implications}

There are many suggestions to be made as a result of the findings, with a few to be mentioned here. This study examined training practice in DEs and MNEs in the KSA. Gibb (1999) analysed a small size firm as unrecognising a number of important strategic HRM practices, such as training. The small size of DEs was found to be a factor in their failure to recognise training as advantageous due to the shortage of methods on formal training within DEs. This shortage of training was measured amongst MNEs; this was a forward step to improving the efficiency in DEs.

\section{Recommendations}

Mustapha (2009) noted that the private sector of DEs and MEs, in some parts of the non-western region, have a shortage of interest in various HR practices. More specifically, there is a shortage of HRM in the Kingdom of Saudi Arabia due to limited study in this area (Anderson, Ahmed \& Costa, 2012; Fadhel, 2007; Al-Dosary \& Rahman, 2009). Additionally, this research will add value to existing literature in the Saudi context, including in the area of weak recent economy (2016) and the breakdown of medium, small and larger firms in Saudi Arabia, this research affords special importance to MNEs and DEs in maintaining continued improvement in HRM.

Furthermore, the researcher suggested HR directors with long experience as being required to invite new employees to enrol on training course more so than old employees in order to increase their experience and move new employees towards work hard. This opinion was found in the same results of the research that the linkage between professional employees and training practice was against. For example, employees with long experience were found to have been involved in little training in DEs and MNEs. 
INTERNATIONAL JOURNAL OF ACADEMIC RESEARCH IN BUSINESS AND SOCIAL SCIENCES Vol. 8, No. 9, Sept. 2018, E-ISSN: 2222-6990 @ 2018 HRMARS

\section{Conclusion}

Human resource systems in training that were less developed focused mainly on the administrative roles within the organisation. The HR system in the highly developed systems focused mainly on the HR functions as opposed to the administrative roles. The gaps identified in HR systems for the DEs and the MNEs would only be reduced through the adoption of learning HR systems. The DEs can learn some of the practices used in MNEs. The differences identified played a crucial role in providing a clear picture that new firms ought to venture into the Saudi market or other similar markets. Additionally, the identified differences indicate that the Saudi market provides a favourable environment to multinational firms. Utilisation of the proper HR practices will ensure that firms retain their competitive advantage in an evolving business environment. For instance, if the HRM selected the best employee for a job position, the entity will then enjoy maximum benefits due to the strength in the training in MNEs, they enjoy fewer turnovers than DEs. A business that adopts strong HR practices will not have to deal with high turnover. All these factors of development training system and enhancing the domestic firm to continue working in the Saudi market and increasing GDP economy will support the Saudi Arabia's vision 2030.

\section{References}

Adler, N.J. and Jelinek, M. (1986), 'Is Organization Culture Bound?', Human Resource Management, 25, 1, 73-90.

Al-Dosary, A. S., \& Rahman, S. M. (2009), 'The role of the private sector towards Saudization (localization), International Journal of Arab Culture, Management and Sustainable development, 1(2), 131-143.

Arthur, J.B. (1994), 'Effects of human resource systems on manufacturing performance and turnover' Academy of Management Journal, 37, 3, 670-687.

Anderson, N., Ahmed, S., \& Costa, A. C. (2012), Applicant Reactions in Saudi Arabia:

Organizational attractiveness and core - self-evaluation. International Journal of Selectio and Assessment, 20(2), 197- 208.

Aycan, Z. (2005), 'The Interplay between Cultural and Institutional/structural Contingencies in Human Resource Management Practices', International Journal of Human Resource Management, 16, 1083-1119.

Andrews, T.G. and Chompusri, N. (2005), 'Temporal dynamics of cross vergence: institutionalizing MNC integration strategies in post-crisis ASEAN', Asia Pacific Journal of Management, 22, 5-22.

Akhtar, S., Ding, D. Z. and Ge, G. (2008), 'Strategic HRM practises and their impacts on company performance in Chinese enterprises', Human Resource Management, 47, 1, 15-32.

Ahmad, S., \& Schroeder, R. (2003), 'The impact of human resource management practices on 
INTERNATIONAL JOURNAL OF ACADEMIC RESEARCH IN BUSINESS AND SOCIAL SCIENCES Vol. 8, No. 9, Sept. 2018, E-ISSN: 2222-6990 (C) 2018 HRMARS

operational performance: Recognizing country and industry differences', Journal of Operations Management, 21, 1, 19-43.

Booth, A. (1993), 'Private sector training and graduate earnings', The Review of Economics and Statistics, 75, 1, 164-70.

Bartlett, C.A. and Ghoshal, S. (1987) 'Managing across Borders: New Strategic Requirements', Sloan Management Review, Summer: 7-17.

Bartlett, C.A. and Ghoshal, S. (1998), Managing across Borders: The Transnational Solution, 2nd edn, Boston, MA: Harvard Business School Press.

Batt, R. (2002), 'Managing customer services: Human resource practices, quit rates, and sales growth', Academy of Management Journal, 45, 3, 587-597.

Barney, J.B. and Wright, P.M. (1998), 'On becoming a strategic partner: The role of human resources in gaining competitive advantage', Human Resource Management, 37, 1, 31-46.

Baron, J. (1988), 'The employment relation as a social relation', Journal of Japanese and international Economies, 2, 492-525.

Boxall, P. and Purcell, J. (2003), 'Strategy and Human Resource Management'. New York:Palgrave Macmillan.

Brewster, C. and Bournois, F. (1991), 'Human Resource Management: A European Perspective', Personnel, Review, 20, 6, 4-13.

DeCenzo, D. and Robbins, S. (2005), 'Fundamentals of human resource management', NJ: Wiley.

Dearden, L., Reed, H. and Van Reenen, J. (2006) 'The Impact of Training on Productivity and Wages: Evidence from British Panel Data'

Dyer, L., Kochan, T. A., \& Batt, R. (1992), 'International human resource studies: A framework for future research Comparative Study', California Management Review, 40, 4, 133- 155.

Farnham, David. (2010). ‘Human Resource Management in Context: Strategy, Insights and Solutions' 3rd London: CIPD.

Fadhel, A. (2007), 'HRD in Saudi family business companies an independent MBA research project supervised by M. Achoui, Department of Management and Marketing-KFUPM', Saudi Arabia. 
INTERNATIONAL JOURNAL OF ACADEMIC RESEARCH IN BUSINESS AND SOCIAL SCIENCES Vol. 8, No. 9, Sept. 2018, E-ISSN: 2222-6990 (C) 2018 HRMARS

Forstenlechner, I. (2009), 'Workforce localization in emerging Gulf economies: the need to finetune HRM'.

Gibb, Stephen (1999), 'The Usefulness of Theory: A Case Study in Evaluating Formel Mentoring Schemes'

Kalleberg, A.L. and Moody, J.W. (1994), 'Human resource management and organizational performance', American Behavioural Scientist, 7, 37, 948-962.

Lawler, J., Jain, H., Venkata Ratnam, C. and Atmiyananda, V. (1995), 'Human resource management in developing economies: a comparison of India and Thailand', International

Journal of Human Resource Management, 6, 319-346.

Mustapha, M. A. (2009) 'Human resource development in Gulf countries: an analysis of the trends and challenges facing Saudi Arabia,' Human Resource Development International, 12:1, 35-46, DOI: 10.1080/13678860802638826.

Mohamed, F., Singh, S., Irani, Z., and Darwish, T. (2012), 'An Analysis of Recruitment, Training, and Retention Practices in Domestic and Multinational Enterprises in the Country of Brunei Darussalam,' The International Journal of Human Resource Management, 24, 2054-2081.

Muller, M. (1998), 'Human Resource and Industrial Relations Practices of UK and US Multinationals in Germany', The International Journal of Human Resource Management, 9, 4, 732-749.

Harel, G. H., \& Tzafrir, S. (1999), 'The Effect of Human Resource Management Practices on the Perceptions of Organizational and Market Performance of the Firm'. Human Resource Management, 38, 185-200.

Winterton, J. (2007), 'Training, development and competence' in P. Boxall, J. Purcell and P. Wright (eds.), The Oxford Handbook of Human Resource Management, Oxford University Press, Oxford.

Waterman, R., Waterman, J., Collard, B., (1994), 'Toward a career-resilient workforce,' Harvard Business Review, Vol.72, No.4, pp.87-95.

Singh, S., Mohamed, F., and Darwish, T. (2013), 'A comparative study of performance appraisals, incentives and rewards practices in domestic and multinational enterprises in the country of Brunei Darussalam,' The International Journal of Human Resource Management, 25, 2054-2081.

Robbins, S. P., \& DeCenzo, D. A. (1998), 'Fundamentals of management: Essential concepts and applications.' Upper Saddle River, N.J: Prentice Hall. 
INTERNATIONAL JOURNAL OF ACADEMIC RESEARCH IN BUSINESS AND SOCIAL SCIENCES Vol. 8, No. 9, Sept. 2018, E-ISSN: 2222-6990 (C) 2018 HRMARS

Way, S. (2002), 'High performance work systems and intermediate indicators of firm performance within the US small business sector', Journal of Management, 28, 765-785.

Wilson, I., \& Madsen, S. R. (2008), 'The influence of Maslow's humanistic views on an employee's motivation to learn.' Journal of Applied Management and Entrepreneurship, 12(2), 46-62.

Snape Ed, Thompson D, Yan F.K and Redman T. (1998) 'Performance appraisal and culture: practice and attitudes in Hong Kong and Great Britain,' The International Journal of Human Resource Management, 9:5, 841-861, DOI: 10.1080/095851998340838.

Royal Embassy of Saudi Arabia (2015), https://www.saudiembassy.net/press-releases/2015.

Shiwaku K., (2014) 'Comparative study on teacher training for school disaster management in Armenia and Japan', Disaster Prevention and Management, Vol. 23 Issue: 2, pp.197211, https://doi.org/10.1108/DPM-12-2012-0144.

Wong, G. and Bimbaum-More, P. (1994), 'Culture, context and structure: a test on Hong Kong banks', Organization Studies, 15, 1, 99-123.

Snape, E. and Redman, T. (2010), 'HRM Practices, Organizational Citizenship Behaviour, and Performance' A Multi-Level Analysis'. 